\title{
Housing Affordability in Czech Regions and Demographic Behaviour - Does Housing Affordability Impact Fertility?*
}

\author{
TOMÁŠ KOSTELECKÝ and JANA VOBECKÁ** \\ Institute of Sociology AS CR, Prague
}

\begin{abstract}
The article examines the relationship between housing affordability and fertility in the Czech Republic after 1989. An analysis of national data suggests that improving housing affordability might be a factor behind the rise of fertility that has been observed since the beginning of the 2000s. The regional variation in fertility is generally lower than the regional variation of indicators of both housing affordability and the economic situation. Although the number of children born increased noticeably, total fertility did not increase at the same pace, and its regional patterns remained rather stable. The most important factor that influences the regional variation in fertility is the education of women, particularly young women. When the education of women is controlled for, housing affordability plays an important role in explaining the regional variation in fertility - both the total fertility rate and the timing of childbearing.
\end{abstract}

Keywords: housing affordability, fertility, Czech regions

Sociologický časopis/Czech Sociological Review, 2009, Vol. 45, No. 6: 1191-1213

\section{Introduction}

The demographic behaviour ${ }^{1}$ of individuals is influenced by many different factors. Some of these factors are of a biological nature (e.g. age or health), others are cultural (e.g. religious or moral values), yet some of the factors that influence demographic behaviour are socio-economic (like education, incomes, or unemployment). ${ }^{2}$ While it is quite difficult to predict the demographic behaviour of an

\footnotetext{
* This article was prepared with the support of research grant WD-05-07-3 of the Ministry of Regional Development of the Czech Republic.

** Direct all correspondence to: Tomáš Kostelecký, Jana Vobecká, Institute of Sociology, Academy of Sciences of the Czech Republic, Jilská 1, 11000 Prague 1, Czech Republic, e-mail: tomas.kostelecky@soc.cas.cz, jana.vobecka@soc.cas.cz.

${ }^{1}$ Demographic behaviour includes all aspects of behaviour connected to human reproduction. In practice it comprises fertility, morbidity, abortions, mortality, marriage, divorces and migration.

${ }^{2}$ Socio-economic factors may influence demographic behaviour directly or, as Easterlin [1976: 417] reminds us, through the 'interplay between aspirations and resources people have to satisfy their aspirations'.
}

(C) Sociologický ústav AV ČR, v.v.i., Praha 2009 
individual, it is easier to predict the aggregate indicators that describe the demographic behaviour of the whole population, provided that we know the characteristics of the population, the conditions in which the population lives, and the relations between demographic behaviour and the underlying factors.

On the macro level of aggregated indicators, it is possible to estimate how fertility is influenced by the structural and biological characteristics of populations, like the number of women of reproductive age, mortality rates, or the share of infertile women in the population. It is somewhat more complicated to estimate the effects of cultural factors on the demographic behaviour of populations, but at least a rough estimate is possible because many of the cultural characteristics of the population (e.g. the percentage of Catholics or the perceived ideal number of children in a family) change only slowly over time and the relationship between these characteristics and demographic behaviour remains relatively stable. Estimating the effects of socio-economic factors on demographic behaviour is, however, a tough task. This is because the relations between some socio-economic phenomena and demographic behaviour are not simply 'cause and effect' in nature, and, moreover, the socio-economic conditions under which people make their reproductive decisions often change quite dramatically over a relatively short period of time, while demographic behaviour not necessarily so.

This article obviously cannot deal with the effects of all possible underlying factors on all aspects of demographic behaviour. As the title suggests, we concentrate on the relationship between one specific socio-economic factor - housing affordability - and one aspect of demographic behaviour - fertility - from the perspective of Czech regions. The main purpose of this article is to examine the potential impact of differences in housing affordability among the regions of the Czech Republic on regional variation in fertility. ${ }^{3}$ The key question asked is whether housing affordability influences the reproductive decisions of Czech households. If the answer to the main question is affirmative, then we would like to know which aspects of fertility are influenced, in what way, and to what extent.

The article consists of four sections. After a brief discussion of the scientific literature on the potential impact of housing conditions on demographic behaviour, specifically, different aspects of fertility, there is a methodological section that provides information on the definitions of the indicators we used and the description of the methods we applied in the analytical part of the study. The third section is devoted to the examination of the relationship between fertility and economic conditions in the Czech Republic. Finally, the fourth section provides the results of an analysis of relationships between housing affordability and different aspects of fertility in Czech regions.

\footnotetext{
${ }^{3}$ In this article, we understand housing affordability as an independent variable and fertility as the dependent variable. We are well aware that the reverse causal direction could also be examined (e.g. how different levels of fertility impact housing affordability), but in the conditions of the Czech Republic our approach is more appropriate.
} 


\section{Do housing conditions affect fertility?}

Although studies of the relationship between fertility and socio-economic factors are plentiful, since Becker [1981] not too many texts have been published that deal specifically with the relationship between fertility and housing conditions. Moreover, when the relationship between fertility and housing conditions is examined, housing is often considered as a dependent variable in the causal relationship between the two phenomena, as it is assumed that the housing conditions of the household must be adjusted to the number of children and the needs of the household [Courgeau 1985; Goodman 1990; Clark and Huang 2003]. But even those who analyse the impact of children on consumption patterns (including the demand for housing) admit that the causal relation might go in the opposite direction, that is, that 'fertility may be affected by the availability and the cost of housing' [Browning 1992: 1435].

The causal relationship between the availability of housing as an independent variable and fertility behaviour as a dependent variable was often observed in less developed societies or societies where the housing market is controlled by the state. Felson and Solaún [1975] analysed the fertility-inhibiting effect of crowded apartment living in a tight housing market in Columbia, concluding that life in small apartments reduced the fertility of members of lower-middle and upper-working classes. Peled [1969] showed the same type of relationship between the housing shortage and fertility in Israel, Berent [1970] in Eastern Europe and the Soviet Union under Communism, and Paydarfar [1995] in Iranian cities. Another point of view on the same relationship was provided by Tan, Lee and Ratnam [1978], who studied the effects of social disincentive policies on fertility behaviour in Singapore. In an attempt to reduce fertility, in the 1970s the Singapore state introduced a set of policies aimed at discouraging families from having more children. Giving priority to small families in the allocation of the government-subsidised housing units was one of the five policy measures. The analysis showed that this specific housing-related measure for discouraging people from having more children was not particularly effective, as most of the mothers who gave birth to four or more children were already living in state-subsidised apartments.

There are, of course, also studies that deal with the situation in the most developed countries. Goodsel [1937] considered home overcrowding as one of the factors explaining the low fertility level in Swedish cities in the interwar period. Thompson [1938] came to basically the same conclusion while studying the situation in the USA. An interesting study by Murphy and Sullivan [1985] analysed the effects of housing tenure on childbearing in post-war Britain. The authors found that the family size of homeowners was smaller than that of tenants, but the fertility of those living in single-family houses was higher than the fertility of those living in apartments. In a recent study, Kulu and Vikat [2007] analysed fertility differences by housing types in Finland, applying hazard regression to the unique, individual longitudinal data from population registers. The study 
proved that there is significant variation in fertility levels across housing types. Fertility was the highest among couples who lived in single-family houses and the lowest among those who lived in apartments, even when effects of other factors were controlled for. Although the difference was partly attributable to selected moves (those who planned to have a child or more children moved to a single-family house before realising their plans), it was proved that couples living in single-family houses tended to have more kids several years after the move, which suggests that improved housing conditions could encourage increased fertility. A more general view of the relationship between housing and fertility is provided by Mulder [2006] who suggested that fertility is not affected only by the size and type of dwelling or housing tenure, but rather by the whole housing system (including its parameters, like the overall quality of housing, the diversity of housing stock in the market accessible to young people). A similar type of argument is used in a paper by Mulder and Billari [2006], who relate the recent 'lowest-low' fertility observed in South European countries with the existence of a special home-ownership regime that combines the high share of owner-occupation with low access to mortgage - a combination that proved to be discouraging to childbearing among young people. Interestingly for us, Mulder and Billari excluded the countries of Central and Eastern Europe from their analytical framework, despite the prevalence of lowest-low fertility levels in the region, claiming that 'the development of housing markets is still in full swing', but they admitted that low fertility could be impacted by the problems young couples have securing 'housing suitable for forming families' [ibid: 8].

This article aims at contributing to the general debate on the potential impact of housing on fertility by analysing the case of the Czech Republic. More specifically, we are interested in whether regional differences in fertility are caused, at least partially, by regional differences in housing affordability. Before we do so, a short methodological section providing information about the indicators and methods of analysis used is necessary.

\section{Indicators and methods}

In this paper we consider fertility as the dependent variable, housing affordability as an independent variable, and some other socio-economic characteristics as controlled variables. From the multitude of existing fertility level indicators we opted for the total fertility rate and the mean age of mothers at first birth, which can be calculated for both individual regions and the whole country. The total fertility rate (TFR) is defined as the total number of children a woman would have by the end of her reproductive period if she experienced the currently prevailing age-specific fertility rates throughout her childbearing life. We also used the mean age of mothers at first birth, which is calculated from the age-specific fertility rates for the first parity in the individual calendar year. The indicator provided us with information about the timing of first births. 
There are three different approaches to measuring housing affordability: the indicator approach, the reference approach, and the residual approach [Garnett 2000]. In the indicator approach, housing affordability is considered a problem when the ratio between housing costs and household incomes exceeds a normatively determined percentage. In the reference approach, housing affordability is a problem if the housing costs substantially exceed national standards. Finally, in the residual approach, housing affordability is considered a problem when residual income of the household is too low to cover the other basic needs of the household. As Robinson, Scobie and Hallinan [2006: 3] remind us, 'housing affordability also can be viewed from three different perspectives: affordability for renter; affordability for would-be home owners; and affordability for existing homeowners'. In practice, different indicators might vary in terms of how both housing expenditures and household incomes are defined [Lux and Kuda 2008]. We chose two different indicators of housing affordability. The first indicator was the price-to-income ratio that compares the average price of the home/apartment with the average income of the average household [Garratt 2001; Case and Shiller 2003; Rooij 2003]. This indicator, however, takes into account neither the interest rates that mortgage providers demand from potential borrowers nor potential changes in the willingness of banks to actually lend money to potential borrowers. We therefore also considered an alternative indicator of housing affordability: the percentage of households that would qualify for a mortgage to buy an averagely priced, appropriately sized apartment. ${ }^{4}$ This indicator simultaneously takes into account all four important parameters that may determine financial affordability for potential buyers: housing prices, household incomes, interest rates, and the willingness of banks to lend money.

When analysing the relationship between housing affordability and fertility in the regions, we first had to make a difficult decision about which territorial unit should be used. The availability of a large number of indicators suggested the use of administrative regions (NUTS 3), but the low number of such units (only 14) led to a small $\mathrm{N}$ problem that made the use of many standard, statistical, analytical techniques impossible. Therefore, we finally decided to work with 77 districts (NUTS 4) in regional analyses to avoid a small N problem. In return, however, we had to sacrifice some of the variables that are not available at the district level (specifically, the percentage of households that would qualify for a mortgage as a measure of housing affordability) and we had to use a simplified version of the price-to-income ratio (the simple ratio between the average price of a flat per square meter to the average gross salary in the district). We also had to concentrate exclusively on the year 2001, for which some data about districts were available from the 2001 Population and Housing Census. We used different control variables in the regional analyses of the relationship between housing affordability and fertility. These included indicators of economic well-being (measured by average wages, taken from annual statistics produced by the Czech Statisti-

\footnotetext{
${ }^{4}$ Households of different sizes eligible to buy apartments of different sizes.
} 
cal Office), economic distress (measured by the general rate of unemployment, drawn from statistics provided by the Ministry of Labour and Social Affairs), the religiousness of women (measured as the percentage of women in the age cohorts most relevant to reproduction who claimed they belong to a religious denomination $^{5}$ in the 2001 Census), the share of the urban population, which is defined as the proportion of the population living in municipalities that provide more than 2000 jobs plus the population living in suburban municipalities from which more than $50 \%$ of inhabitants commute daily to cities that provide more than 5000 jobs [Vobecká 2009a, 2009b] (calculated from data from the 2001 Census), and indicators of the education of women (the share of women with secondary education and the share of women with tertiary education in the age cohorts most relevant to reproduction - all data from the 2001 Census). It should be noted that all the data used in the analyses were aggregate data. This was not only because individual-level data that would capture the differences among individual districts are not available. In order to analyse the regional aspect of the relationship between housing affordability and fertility data are required that characterise the territorial units of observation, as they describe the environment within which local people make decisions about childbearing. For example, high unemployment in the district may influence decisions of all young people living in the district, not only those who are actually unemployed. However, readers should be aware that we cannot infer the individual-level relationships between the variables from the aggregate data because of the danger of 'ecological fallacy' [Robinson 1950]. Thus, the relationships that we find pertain to districts and district populations, but they may not necessarily be the same as the relationships found at the level of individuals.

The actual analysis of the data was conducted in two steps. In the first step, we described the societal context in which the changes in fertility have occurred in the last nearly twenty years of post-communist transformation. In the second step, we concentrated on what is the core of our inquiry - a more detailed analysis of the relationships between housing affordability and fertility on the level of the Czech regions. We used the standard modelling technique of multiple linear regression, which enabled us to specify different indicators of fertility as dependent variables and the indicator of housing affordability as an independent variable, while controlling for the effects of the other variables, and thus to test whether fertility in the districts was influenced by housing affordability in the districts.

\footnotetext{
${ }^{5}$ Only $32 \%$ of inhabitants of the Czech Republic were religious according to the 2001 Census - over four-fifths of them were Roman Catholics and most of the rest members of various Protestant denominations. The majority of the population, however, is non-religious.
} 


\section{The effects of socio-economic factors on fertility in the Czech Republic}

There are few examples of studies that explicitly concentrate on the relationship between housing conditions and fertility in the Czech Republic. The Czech baby boom after the Second World War was partly viewed as the population's natural reaction to the end of the war (postponed births that were not realised during the war) and partly seen as the secondary effect of fertility of the strong postFirst World War generations. ${ }^{6}$ During the 1950s, however, the average number of children per woman rapidly decreased from 2.8 in 1950 to 2.1 in 1960. Sobotka et al. [2003] attribute the decline in fertility mainly to the high participation of women in the labour market, which forced women to combine the traditional role of house-keeping and childcare with holding a full-time job, but also to the introduction of liberal divorce legislation in 1950 and the legalisation of abortion in 1957. But Frejka [1980: 68] also explained declining fertility rates by socioeconomic factors, specifically identifying a chronic housing shortage as one of the underlying factors. Rychtaříková [2007] also referred to the 'difficult housing situation' as one of the factors that caused the fertility decline.

Constantly decreasing fertility rates led the communist government to consider implementing pro-population policy measures. They were not adopted in practice until after the invasion of Soviet/Warsaw Pact troops into Czechoslovakia in 1968, specifically in 1971 and 1972. These measures were the most extensive, comprehensive and the most costly fertility-related population policy measures ever implemented in any developed country. Expenditures on pro-population policy accounted for $10 \%$ of the total budget expenditures of Czechoslovakia at the beginning of the 1970s [Frejka 1980: 71, 89]. The measures comprised substantial a rise of childcare family allowances, the extension of maternity leave, the introduction of maternity grants, and low-interest loans to newlywed couples. It was combined with increased investment into childcare services and mass construction of social housing.

The policy became quite successful in the short term - the average number of children per woman grew from 1.8 in 1968 to 2.4 in 1974. Although the increase could not be fully attributed to the policy measures and the changing socio-economic conditions for childbearing, their effects were undoubtedly important [Rychtaříková 2004; Frejka 1980; Sobotka, Zeman and Kantorová 2003]. The increase of fertility was the most pronounced among women with higher education and women living in larger towns, which were the most receptive to

\footnotetext{
${ }^{6}$ Although a large number of vacated houses became available in Czechoslovakia after the expulsion of the Germans, this should not be considered an important factor behind increased post-war fertility. The post-Second World War baby boom was a phenomenon observed all over the European continent, even in countries that faced housing shortages owing to war damage. Moreover, the ex-German housing stock was unevenly distributed geographically. Much of it was located in the unattractive peripheral areas of the country and, thus, remained unused.
} 
the improvement of conditions for family formation [Rychtaříková 2007]. In the 1980s, the effects of population policy measures gradually vanished and fertility gradually declined.

The collapse of the communist regime in 1989 led to a dramatic change of many state policies. It is possible to claim, however, that the state population policy practically ceased to exist after the regime change. Some measures aimed at financially supporting families had survived the economic transformation (namely child allowances and tax deductions for parents with dependent children), but they lost relevance because the benefits provided no longer represented a substantial portion of the family budget. In time, when unemployment increased substantially and public expenditures on day-care centres were significantly reduced, it became harder for women to combine a full-time job with childcare [Hašková 2005]. At the same time, however, the window of opportunity, far surpassing anything the young generations knew under communism, opened for those with high education, the marketable skills, or the courage to establish their own business. The situations described above represented an environment under which profound changes in fertility patterns were observed. Cohorts of women that were born in the 1970s postponed their childbearing, whereas women born in the 1960s had fewer second-order and third-order births. The change in timing and the further postponement of childbearing by the younger cohorts resulted in a drastic decrease of the total fertility rate. It is a transversal indicator and therefore very sensitive to the changes in timing. The total fertility rate dropped to below 1.2 and remained there throughout the period between 1996 and 2003. Such unprecedentedly low fertility attracted the attention of many demographers, who attempted to identify its causes [e.g. Rychtaříková 1996, 2000a, 2000b; Billari and Kohler 2002; Hamplová, Pikálková and Rychtaříková 2003; Sobotka 2002, 2003; Chase 2003; Sobotka et al. 2008; Klasen and Launov 2006; Frejka 2008]. Some interpret the changes in reproductive behaviour as a result of the structural effects of social and economic uncertainty [e.g. Rychtaříková 1996]. Some view it as part of a complex value change and an attitudinal reaction to new challenges for individuals in the changing societal context, calling the process the second demographic transition [Van de Kaa 1987; Sobotka, Zeman and Kantorová 2003]. Sobotka et al. [2008: 403] conclude that 'the rapidity of observed changes can be explained as the outcome of a simultaneous occurrence of several factors, especially the expansion of higher education, the emergence of new opportunities competing with family life, increasing job competition, rising economic uncertainty in young adulthood, and changing partnership behaviour'. This interpretation combines both the role of structural effects and the role of changing individual and societal values. Opportunities to study and receive a higher education increased, and so did the market value of education in the labour market, which resulted in higher enrolments of young women and consequently a decrease of the number of young mothers. The proportion of women between the ages of 20 and 24 that were enrolled in tertiary education increased from 13\% in 1995 
to $30 \%$ in 2003 [Sobotka et al. 2008]. Moreover, the gap between graduation and motherhood sharply increased [Klasen and Launov 2006]. The average age at the first child delivery increased, especially among women without secondary education [Rychtaříková 2007]. The competition on the job market led young graduates to prefer gaining relevant professional experience before starting a family. Particularly for women with high education it became difficult to combine a professional career and motherhood, as the prevailing public opinion considered long maternity leave the best option for children [Kulhavý and Bartáková 2007; Hašková 2005] while the competitive labour market tolerated only short maternity leaves for women intent on pursuing their career. The social distress connected with the emergence of unemployment and economic uncertainty for low-skilled employees also played a certain role in the decrease of fertility. The rising costs of childbearing led to the widespread opinion that a sharp decline in the standard of living is unavoidable after the birth of a child [Fialová et al. 2000]. Among young people without tertiary education there emerged a widespread fear that motherhood signifies a threat to a woman's professional career and personal isolation [Kulhavý and Bartáková 2007]. The emergence of new opportunities competing with family life, including the opportunity to travel, an orientation towards consumerism of every kind, and self-development may play an important role in the postponement of childbearing or the decision to have fewer or no children. Nevertheless, the polls show that the young generation still rates life as a couple with children (usually two) as the highest value for their lives [Štastná 2007].

The breakdown of communist rule in 1989 also dramatically changed the situation in housing. The profound changes to 'the rules of the game' in the housing market, the sharp decrease of housing construction, and the dramatic increase of housing prices [Lux et al. 2003; Sýkora and Posová 2007] that were simultaneously accompanied by the dramatic decrease of fertility rates raised the question of whether (or to what extent) the changes in housing affordability may be responsible for the fertility decline.

The first 'Housing Policy Concept' that was passed by the Czech government in 1991 'foresaw complete withdrawal of the state from the housing investment and the creation of a real state market' [Buzar 2005: 385]. Indeed, the state was no longer much involved in the housing market, limiting its interventions to financial support for building savings banks ${ }^{7}$ and to passing the legislation that allowed the constitution of mortgage banks. However, only several years after the start of the economic transformation Musil [1995: 1681] described the housing situation of newly formed households as 'critical' and 'particularly severe for young people'. Buzar [2005: 393] pointed out that 'low income young families and reti-

\footnotetext{
7 The state pays a special bonus on savings that are deposited in special building savings banks, so this type of deposits became quite popular among the population. Only a portion of the accumulated money is in practice lent to borrowers interested in purchasing housing, which makes this an ineffective and costly policy [Sunega 2005].
} 
rees' were hardest hit by problems with housing costs. In demographic literature, the potentially existing relationship between the difficult housing situation of families and the decline of fertility is often mentioned, but housing affordability is just one of many different socio-economic factors that might influence the levels or timing of fertility. Sobotka et al. [2008] consider declining housing affordability as one of the relevant factors for explaining decreasing fertility, especially for less well-to-do households. Similarly, Klasen and Launov [2006] identified housing conditions as among the most important reasons cited for the decline of fertility (together with the lack of childcare facilities and in the context of the higher educational attainment of women).

The deep and long-lasting decline of fertility did not attract much attention from the early post-communist governments, which considered the phenomenon as a natural reaction to the new situation and the expression of the free will of the young generations. When the Social Democrats replaced the right-wing parties in the national government for the first-time in 1998, the attitude of the government changed - it declared family policy as one of its priorities. In practice, however, the first policies supporting young families were adopted only several years later and were rather modest in their scope and relevance. A special state subsidy for the mortgage debt payment for young families (both husband and wife had to be younger than 36) was introduced in 2002. The state also introduced limited support for the construction of social housing but newly constructed apartments were very limited in number and, moreover, were usually not used for the housing of young couples. The first comprehensive family policy was approved only in 2005. It introduced the possibility of legal work during parental leave without reducing the maternity benefits while noticeably increasing the benefits themselves. National Family Policy [2005: 21] also declared housing affordability a crucial factor in decision making of young couples whether to have a child or enlarge their families. The document nevertheless declared municipalities to be responsible for solving the housing affordability problem, claiming that municipalities are the sole providers of social housing. While effects of the state propopulation policies (or the lack of them) is difficult to measure, the reproductive decisions of young Czechs after 1989 can be interpreted in relation to the general economic or specifically housing conditions under which they live. Figure 1 aims to illustrate the changes in the total fertility rate in the macro-economic, social and housing affordability context. All indicators are all expressed in Z-score to provide a comparable measurement scale. ${ }^{8}$

\footnotetext{
${ }^{8}$ Unfortunately, not all the indicators are available for the whole period between 1989 and 2007. Reliable data about the number of completed flats are available since 1993. The indicators of housing affordability can only be computed since 2000, when the regular monitoring of housing prices started. Moreover, the proportion of households who qualify for a mortgage for 'an average apartment' cannot be calculated for 2007, when the national system of the subsistence minimum was abolished and the mortgage banks consequently
} 
Figure 1. The total fertility rate and the basic economic and housing market indicators in the Czech Republic after 1989 (all indicators expressed in Z-score)

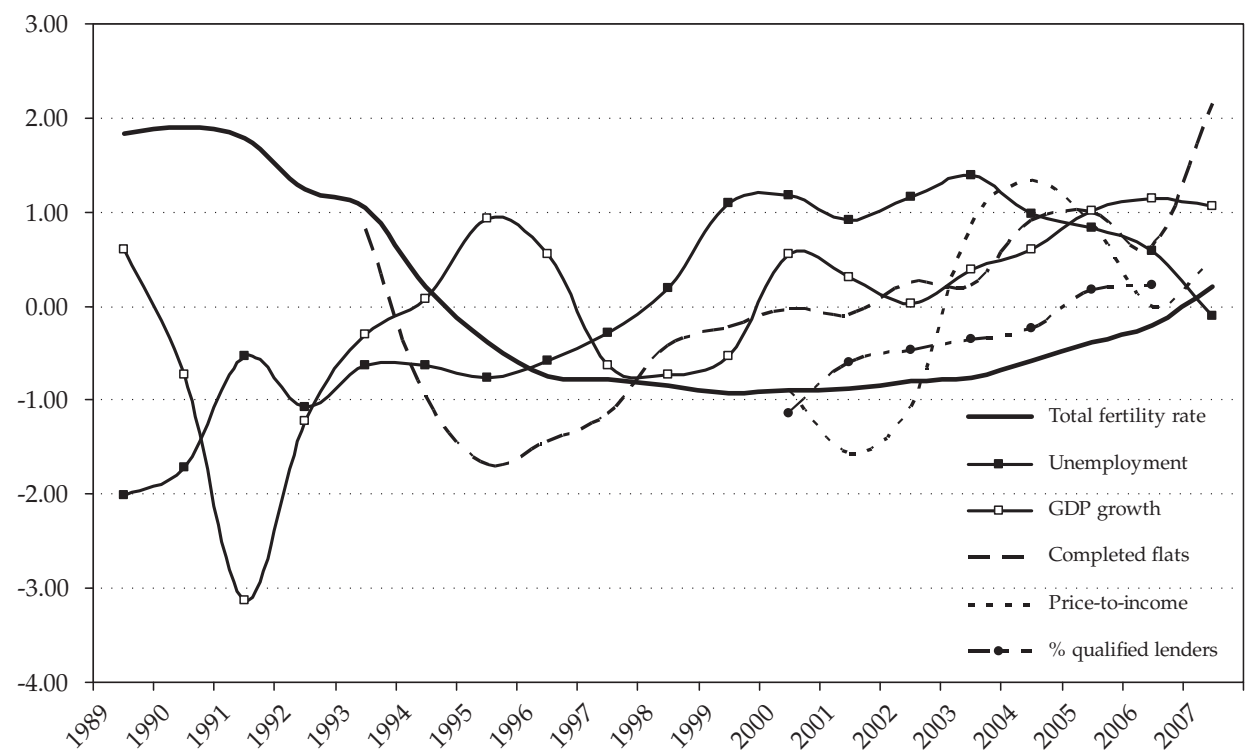

Source: Authors' calculations based on data from the Czech Statistical Office, the Institute of Regional Information, the Ministry of Labour and Social Affairs, and the Czech National Bank.

It is clear from the figure that the total fertility rate declined rapidly in the first half of the 1990s and only started to recover after the year 2000. Since 2004 the total fertility rate has been rising more noticeably. The mean age of mothers giving births was no longer rising as quickly as in the 1990s. But even after increasing for seven years the total fertility rate remained substantially lower than at the beginning of the 1990s.

In 1990 and 1991 when the economy was hit by the transformation problems and the GDP rapidly declined, total fertility remained basically unchanged. Between 1993 and 1996, when the economy witnessed a quick post-transformation recovery, total fertility declined the most rapidly. Between 1997 and 2002 fertility remained stable and very low, while GDP was witnessing a second post-transformation decline, followed by a substantial recovery. Only after 2003 was the

ceased to apply comparable nation-wide criteria for determining the bonity of clients. With regard to the data from the chart, readers should be aware that for each indicator, the zero value of the Z-score means the average value of the respective indicator in the period for which data are available. 
modest rise of the total fertility rate accompanied by a rise of GDP growth. The unemployment rates were growing when fertility was declining and vice versa, nevertheless, the time coincidence of the two phenomena does not necessarily mean that any direct causal relationship between unemployment and fertility exists. The observation of the situation in the housing market is naturally limited only to the periods for which data on housing are available. The total fertility rate was growing at the same time as the percentage of potential borrowers who would qualify for a mortgage (i.e. as ownership housing became more affordable) was also growing. An increase in the affordability of ownership housing was observed despite the rise of the price-to-income ratio. This was made possible by the sharp decrease of the inflation rate from over $10 \%$ in 1998 to about $2 \%$ in 1999, which was followed by a profound drop in interest rates. Thus, the price of ownership housing was rising, but cheaper mortgages made it more affordable for a growing portion of households.

The total fertility rate is an indicator that is rather sensitive to short-term socio-economic changes. The data in Figure 1 suggest that at least after 2000 the decline of unemployment and the rising affordability of ownership housing might have positively affected the decision of people to have the children that had been postponed and were not born in the previous period of economic insecurity. But it should be underlined that this is more a hypothesis than a statement about a causal relationship, not only because the data are incomplete, but also because the effects of too many other potential underlying factors are not (and probably cannot be) controlled for. It should also be mentioned that changes in total fertility rates depend also on other demographic factors such as the timing of births [Bongaarts and Fernet 1998]. Changes in the total fertility rate, however, was so deep in the observed period that it can also reflect the more profound changes of values and attitudes concerning reproductive behaviour.

\section{Housing affordability and fertility in Czech districts: does housing affordability influence regional variations in fertility?}

To get more detailed information about the possible impact of housing affordability on fertility, we conducted analyses centred on the relationship between the different features of fertility and housing affordability in Czech districts. If housing affordability affects fertility we can expect that regional differences in housing affordability will be related to the regional differences in fertility, provided that the effects of other potential underlying variables are controlled for. In regional analyses the total fertility rate and mean age of mothers at first birth ${ }^{9}$ were the dependent variables, while the price-to-income ratio defined as the ratio

\footnotetext{
${ }_{9}$ Owing to the relatively small number of children born annually in some smaller districts we used the three-year averages (2000-2002) of both indicators.
} 
Table 1. Descriptive statistics for variables used in the regression models

\begin{tabular}{|c|c|c|c|c|c|c|}
\hline & $\mathrm{N}$ & $\begin{array}{l}\text { Mini- } \\
\text { mum }\end{array}$ & $\begin{array}{l}\text { Maxi- } \\
\text { mum }\end{array}$ & Mean & $\begin{array}{c}\text { Std. } \\
\text { Deviation }\end{array}$ & Data source \\
\hline $\begin{array}{l}\text { Total fertility } \\
\text { rate }\end{array}$ & 77 & 1.029 & 1.315 & 1.163 & 0.05 & $\begin{array}{l}\text { CSO, demographic } \\
\text { statistics 2000, 2001, } \\
2002\end{array}$ \\
\hline $\begin{array}{l}\text { Mean age of } \\
\text { mothers at the } \\
\text { first birth }\end{array}$ & 77 & 23.9 & 27.4 & 25.0 & 0.57 & $\begin{array}{l}\text { CSO, demographic } \\
\text { statistics 2000, 2001, } \\
2002\end{array}$ \\
\hline $\begin{array}{l}\text { Unemployment } \\
\text { rate }\end{array}$ & 77 & 2.5 & 21.4 & 8.6 & 3.96 & $\begin{array}{l}\text { Ministry of Labour } \\
\text { and Social Affairs, } \\
2001\end{array}$ \\
\hline $\begin{array}{l}\text { Average salary } \\
\text { (thousands CZK, } \\
\text { monthly }\end{array}$ & 77 & 11.2 & 20.8 & 13.3 & 1.40 & CSO 2001 \\
\hline $\begin{array}{l}\text { Education } \\
\text { women 25-29 }\end{array}$ & 77 & 39.0 & 69.1 & 50.6 & 5.00 & CSO, Census 2001 \\
\hline $\begin{array}{l}\text { Religiosity } \\
\text { women 25-29 }\end{array}$ & 77 & 5.7 & 57.8 & 21.0 & 12.47 & CSO, Census 2001 \\
\hline $\begin{array}{l}\text { Urbanisation } \\
\text { rate }\end{array}$ & 77 & 29.4 & 100.0 & 60.5 & 17.18 & $\begin{array}{l}\text { Vobecká [2009a, } \\
\text { 2009b] on data from } \\
\text { CSO, Census } 2001\end{array}$ \\
\hline Price-to-income & 77 & 19.8 & 88.5 & 43.3 & 13.27 & $\begin{array}{l}\text { Authors' calcula- } \\
\text { tions on data from } \\
\text { IRI and CSO }\end{array}$ \\
\hline
\end{tabular}

Notes: $\mathrm{N}$ stands for the number of districts in the Czech Republic, as the analysis is done on the aggregated data by districts. CSO: Czech Statistical Office; IRI: Institute for Regional Information.

Source: Authors' calculations.

between the average price per square metre of a flat in the district and the average monthly gross salary in the district ${ }^{10}$ was the independent variable. After eliminating the most highly inter-correlated variables we identified several controlled variables that contribute the most to the explanatory power of the regression models: the average salary in the district as the measure of its economic prosperity, the general rate of unemployment as a measure of the economic distress of some specific groups of the population, ${ }^{11}$ the proportion of women aged 25-29

${ }^{10}$ This was expressed in percentages: the indicator shows what percentage of gross monthly salary is necessary to purchase one square metre of a flat in a given district.

${ }^{11}$ The average salary and the unemployment rate are somewhat surprisingly not significantly correlated at the level of districts. 
Table 2. Regression model explaining the regional variation in the mean age of mothers at first birth in 2001

\begin{tabular}{|c|c|c|c|c|c|c|c|}
\hline & \multicolumn{2}{|c|}{$\begin{array}{c}\text { Unstandard- } \\
\text { ised coefficients }\end{array}$} & \multirow{2}{*}{$\begin{array}{c}\begin{array}{c}\text { Standardised } \\
\text { coefficients }\end{array} \\
\text { Beta } \\
\end{array}$} & \multirow{2}{*}{$\begin{array}{c}\mathrm{t} \\
\begin{array}{c}\text { Toler- } \\
\text { ance }\end{array}\end{array}$} & \multirow{2}{*}{$\begin{array}{l}\text { Sig. } \\
\text { VIF }\end{array}$} & \multicolumn{2}{|c|}{$\begin{array}{l}\text { Collinearity } \\
\text { statistics }\end{array}$} \\
\hline & B & $\begin{array}{l}\text { Std. } \\
\text { Error }\end{array}$ & & & & B & $\begin{array}{l}\text { Std. } \\
\text { Error }\end{array}$ \\
\hline (Constant) & 22.671 & 0.336 & - & 67.543 & .000 & - & - \\
\hline $\begin{array}{l}\text { Unemployment } \\
\text { rate }\end{array}$ & -0.045 & 0.009 & -.312 & -5.267 & .000 & .585 & 1.710 \\
\hline Average salary & 0.103 & 0.028 & .254 & 3.655 & .000 & .427 & 2.344 \\
\hline $\begin{array}{l}\text { Education } \\
\text { women 25-29 }\end{array}$ & 0.102 & 0.015 & .482 & 6.651 & .000 & .393 & 2.546 \\
\hline $\begin{array}{l}\text { Religiosity } \\
\text { women 25-29 }\end{array}$ & 0.003 & 0.003 & .056 & 1.014 & .314 & .671 & 1.489 \\
\hline $\begin{array}{l}\text { Urbanisation } \\
\text { rate }\end{array}$ & -0.002 & 0.002 & -.055 & -.819 & .416 & .460 & 2.172 \\
\hline Price-to-income & 0.010 & 0.003 & .238 & 3.754 & .000 & .514 & 1.946 \\
\hline
\end{tabular}

Notes: adjusted R square $=0.844$; Linear regression from the SPPS 15.0 statistical package, method Enter, ordinary least square method of interpolation.

Source: Authors' calculation.

with complete secondary education ${ }^{12}$ as a measure of the level of education of the age cohort that has the highest fertility in Czech society, the percentage of urban (plus suburban) population as a measure of urbanisation, and the percentage of women aged 25-29 who are religious. ${ }^{13}$

The descriptive statistics for the variables included in the model are provided in Table 1.

The data in the table show that the regional variation of the key indicators of fertility is relatively small. The total fertility rate varies from 1.029 (Břeclav District) to 1.315 (Ústí nad Labem District), while the mean age of mothers at first birth ranges from 23.9 (Most District) to 27.4 years (Prague). The regional variation in housing affordability is substantially larger: while in Prague it costs $88.5 \%$ of the local average monthly salary to buy one square metre of residential space, in Most it costs $19.8 \%$ of the local income to do so. The regional variation of controlled variables is higher than that of demographic variables and comparable to that of the indicator of housing affordability.

12 The alternative indicators of a woman's educational level were excluded owing to the high correlation with the selected indicator.

${ }^{13}$ The alternative indicators of religiosity of the population were excluded owing to the high correlation with the selected indicator. 
Table 3. Regression model explaining the regional variation in the total fertility rate in 2001

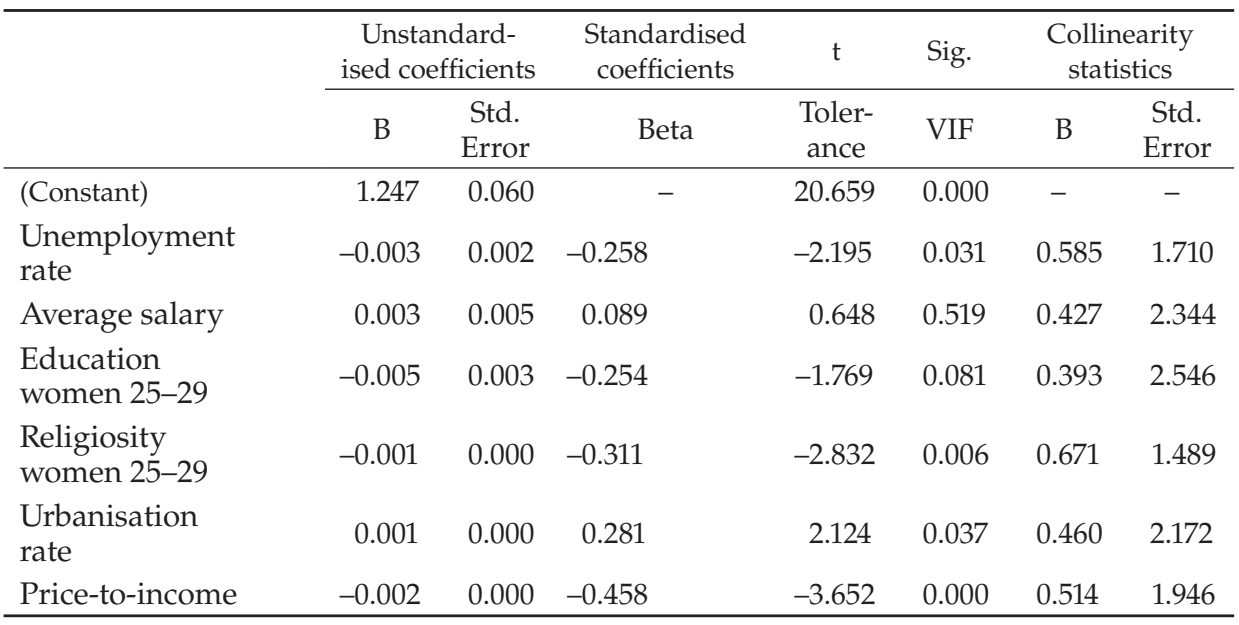

Notes: adjusted R square $=0.386$; Linear regression from the SPPS 15.0 statistical package, method Enter, ordinary least square method of interpolation.

Source: Authors' calculation.

The results of the first model, aimed at explaining the regional variation in the mean age of mothers at first birth, are displayed in Table 2.

The model explaining the regional variation in the mean age of mothers at first birth was very successful - it explained $84 \%$ of the total regional variance. Four independent variables in the model were strongly related $(\mathrm{P}<0.01)$ to the dependent variable at the district level. The age of first-time mothers is higher in districts where there is a lower unemployment rate, higher average salary, higher level of education of women aged 25-29, and higher price-to-income ratio. Such a combination of independent variables is quite easy to interpret. The higher education level of young women expectedly leads to a delay in their decision to become mothers. The higher average salary and the lower unemployment rate indicate more prosperous regions in which a better economic situation and better career prospects contribute to the decision of young people to postpone having children - and this is true even when the effect of the different educational level of women are controlled for. Finally, the high housing prices in relation to local salaries (that is low affordability of housing) also increase the average age of first-time mothers. The costly housing discourages young people from having children at a younger age and leads them to postpone reproduction to a later age. This relationship holds even if the differences in the educational level of young women and the differences in the economic situation of districts are controlled for. 
The result of modelling is not so clear when the regional variance in the total fertility rate is to be explained (see Table 3).

This model is much less successful than the previous one - it explains only about $38 \%$ of the total variation, leaving almost two-thirds of the variation unexplained. Only two of the independent variables were found to have a strong relationship $(\mathrm{P}<0.01)$ to the dependent variable - the price-to-income ratio and the religiousness of young women - while another two variables - the unemployment rate and the urbanisation rate - has a somewhat weaker relationship $(\mathrm{P}<0.05)$. The total fertility rate is the highest in districts where the price-to-income ratio is low (that is, where housing is more affordable). Also, the total fertility rate is higher in districts with a lower proportion of religious young women, lower unemployment rate and more urbanised districts. In contrast to the previous model, the combination of independent variables that were statistically significant in the model explaining regional variation in the total fertility rate is rather difficult to interpret. The only independent variable whose effect seems to be clear is the price-to-income ratio. It is not surprising that in districts where housing prices are high in relation to local salaries, the total fertility rate tends to be low. The problem with housing affordability may not only postpone the birth of the first child but may in the end contribute to lower total fertility in the district. However, the effects of other independent variables in the model are less straightforward. The effect of unemployment points in a somewhat different direction than the effect of the same independent variable in the previous model. While in districts with high unemployment the mean age of mothers at first birth tends to be lower, so does the lower total fertility rate. Thus, low unemployment (combined with high salaries) in the district may encourage women to postpone childbearing to a later age, but high unemployment in the district may discourage women from having more children.

The effects of the last two mentioned variables in the model are even more surprising. The total fertility rate is higher in districts with a lower level of religiosity among young women, provided the effects of other variables are controlled for. Such a relationship is somewhat counter-intuitive, as we know from the individual-level data from the 2001 Census [Plodnost... 2003] that religious women have somewhat higher fertility in all age cohorts. As the negative relationship between the levels of religiosity of young women and the total fertility rate is strong and statistically significant even when the religiosity of young women in the district is used as a single independent variable, the negative relationship cannot be explained by the simultaneous effects of other independent variables in the model. Thus, there seems to be two possible explanations for the puzzle. Taking into account that we are working with aggregate and not individual data in our regional analysis, it is possible that we are observing some contextual effects similar to these that were already observed in the case of political behaviour [Kostelecký and Čermák 2004]. It is possible that the fertility of both religious and non-religious young women depends on whether they live in a district with high 
religiosity or in districts where the population is prevailingly non-religious. This could explain why the positive relationship between religiousness and fertility on the individual level could turn into a negative relationship on the aggregate level of districts.

Another possible explanation for the puzzle could be found in the regionally uneven tempo effect on the total fertility rate [Sobotka and Lutz 2009]. We hypothesise that the traditionally more religious districts of South Moravia had both a higher total fertility rate and lower mean age of mothers. The delayed but quicker transition of the population living in South Moravian districts towards the new mode of fertility behaviour could distort the values of total fertility rates and make them less reliable measures of the fertility level. Thus, tempo-adjusted total fertility rates might be better indicators of fertility level in districts. Nevertheless, there is no such indicator available for districts, and consequently, we could not test whether the relationship between fertility and the religiousness of young women in districts changes when the tempo-adjusted total fertility rate is used.

Similarly counter-intuitive is the positive relationship between the urbanisation rate and the total fertility rate in the regression model. The demographic data from the last two decades show that the fertility of the rural population is still higher than the fertility of the urban population when individual socio-economic characteristics are controlled for, at least as far as cohort fertility is concerned [Vobecká 2009a]. Again, from the aggregate data that we have we cannot recognise who contributes to the higher total fertility rate in more urbanised districts. It is possible that it is caused by the higher fertility of the rural population living in more urbanised districts. But it is also possible that in this case the positive relationship between the rate of urbanisation in districts and the total fertility rate can be partly explained by the simultaneous effects of other independent variables in the model, namely, the strong effect of price-to-income ratio. When the effect of housing affordability is controlled for, the statistically significant positive relationship between the rate of urbanisation and the total fertility rate in districts exists. When the effect of housing affordability is not controlled for, the statistical relationship between the urbanisation rate and the total fertility rate in districts disappears.

Finally, it should be mentioned that while the education of young women was the strongest predictor of the mean age of mothers at first birth in districts, the effect of this independent variable is rather weak in the model that explains the regional variation in the total fertility rate. The logic of the relationship is as one would expect - the higher level of education among young women in districts, the lower the total fertility rate in the district - but the strength of relationships is quite low $(\mathrm{P}<0.1)$ when the effects of other independent variables are controlled for. 


\section{Conclusion}

This article examined the relationship between housing affordability and fertility in the Czech Republic after 1989. An analysis of data on the national level revealed that some links between fertility, housing affordability, and indicators of macro-economic development exist, particularly after 2000 when the improvement of the economic situation (the increase of the GDP and the housing construction, the decrease of the inflation and the unemployment) was paralleled by improving affordability of the ownership housing and rising fertility. Thus, the analysis of national data suggested that housing affordability might be one of the factors that influenced the rise of fertility that was observed since the beginning of the 2000s.

To get deeper insight into the potential effects of housing affordability on fertility we analysed data on the district level. We found that the regional variation in fertility is generally much lower than the regional variation in housing affordability and other indicators describing the economic situation, the urbanisation level, and the religious and educational structure of young women. It appears that the regional variation in fertility indicators does not simply mirror the variation in the socio-economic or structural characteristics of individual districts. People's decisions about having children are influenced by other factors that do not vary regionally (or do not substantially vary regionally) and therefore may contribute to less regional variation in fertility; for example, factors like (male or female) infertility, the standardised length of compulsory full-time schooling, or the reproductive plans of young people. ${ }^{14}$

Regression analyses of the relationship between fertility and housing affordability on the district level proved that housing affordability has a significant impact on fertility. Women living in districts with highly affordable housing have their children sooner, while women living in districts with housing affordability problems tend to have their children later (provided that the effect of other important variables describing differences among districts is controlled for). Similarly, the total fertility rate tends to be lower in districts where local housing prices are high in relation to local salaries (that is, housing is less affordable). The results of analyses suggest that problems with housing affordability have a stronger effect on the timing of the childbearing than on the total number of children born per woman of reproductive age. Faced with the problem of high housing prices in some regions, young people living there tend to postpone having children to a later age as they need more time to become financially secure and get a goodpaying job (and eventually to save enough money for a down payment) so that they can acquire the housing they want before realising their reproductive plans. When their housing problem is solved, these young people finally have children,

\footnotetext{
${ }^{14}$ According to Šalamounová [2003], about three-quarters of Czechs consider two children the ideal number of children in a family.
} 
but not necessarily as many children as their counterparts living in regions with more affordable housing and who had their first children at a younger age. However, although at the district level there is a significant negative statistical correlation between the total fertility rate and the mean age of mothers at first birth (Pearson correlation $=-0.299, \mathrm{P}<0.01$ ), the total fertility in district is not a simple function of the timing of childbearing. In other words, in districts where people start their reproductive behaviour later the higher fertility of mothers over thirty partially compensates the lower fertility of mothers under thirty.

The results of our analysis have potentially important implications for anybody considering the implementation of pro-population policies in the Czech Republic. While it is true that the problem with housing affordability does influence the fertility of the young population in the Czech Republic, it is important to remember that housing affordability is not the only factor that affects fertility behaviour. The most important of the other factors influencing the regional variation in fertility is the education of young women. The higher the education level of young women, the lower the total fertility rate and (especially) the higher the average age of first-time mothers in the district. The economic situation in districts also has a significant impact on the fertility behaviour of the local population. Thus, any measures targeted at improving housing affordability for young people in order to increase their fertility rate must necessarily be part of a complex, coherent set of pro-natal policies or else they are doomed to fail. If policy measures to increase housing affordability for young people were implemented, it is likely that they would mainly impact the timing of childbearing and much less the total fertility rate. Thus, a careful cost-benefit analysis must precede any practical action in this policy field.

TOMÁš KosteleCKÝ is a senior researcher at the Institute of Sociology of the Academy of Sciences of the Czech Republic and head of the Department of Local and Regional Studies. His research interests have long included the spatial aspects of human behaviour, regional and comparative policy, the political effects of metorpolitanisation and suburbanisation. He regularly publishes work in domestic and foreign journals and books. He was the Woodrow Wilson International Fellow in Washington D.C., a Japan Society for the Promotion of Science scholar at the University of Hokkaido in Sapporo, Marie Curie Intra-European Fellow at CNRS/Science Po in Bordeaux, and had a Fulbright Fellowship at the University of Southern California in Los Angeles.

JANA VOBECKÁ is a junior researcher at the Institute of Sociology of the Academy of Sciences of the Czech Republic. She is also a doctoral student of demography at Charles University in Prague and at Université de Bourgogne in Dijon, France. Her main research interests are spatial population dynamics, internal migration, local governance and the population development of the Jews in Bohemia before 1939. 


\section{References}

Becker, G. 1981. A Treatise on the Family. Cambridge: Harvard University Press.

Berent, J. 1970. 'Causes of Fertility Decline in Eastern Europe and the Soviet Union.' Population Studies 24 (July): 247-278.

Billari, F. C. and H.-P. Kohler. 2002. 'Patterns of Lowest-Low Fertility in Europe'. Max Planck Institute for Demographic Research Working Papers. Retrieved 14 December 2009 (http://ideas.repec.org/p/dem/wpaper/wp-2002-040.html).

Bongaarts, J. and G. Feeney. 1998. 'On the Quantum and Tempo of Fertility.' Population and Development Review 24 (2): 271-291.

Browning, M. 1992. 'Children and Household Economic Behavior.' Journal of Economic Literature 30: 1434-1475.

Buzar, S. 2005. 'The Institutional Trap in the Czech Rental Sector: Nested Circuits of Power, Space and Inequality.' Economic Geography 81 (4): 381-405.

Case, K. and R. Shiller. 2003. 'Is There a Bubble in the Housing Market? An Analysis.' Paper presented for the Brookings Panel on Economic Activity.

Chaloupková, J. 2005. 'Faktory ovlivňující dělbu domácí práce v českých domácnostech a hodnocení její spravedlnosti.' (Factors Influencing and the Division of Labour in Czech Households and an Assessment of Its Fairness) Sociologický časopis/Czech Sociological Review 41(1): 57-77.

Chase, R. S. 2003. 'Household Fertility Responses Following Communism: Transition in the Czech Republic and Slovakia.' Journal of Population Economics 16: 579-595.

Clark, W. A. and Y. Huang. 2003. 'The Life Course and Residential Mobility in Britain Housing Markets.' Environment and Planning A 35: 323-339.

Courgeau, D. 1985. 'Interaction between Spatial Mobility, Family and Career Life Cycle: a French Survey.' European Sociological Revieww 1 (2): 139-162.

Easterlin, R. A. 1976. 'The Conflict between Aspirations and Resources.' Population and Development Review 2 (3-4): 417-424.

Felson, M. and M. Solaún. 1975. 'The Fertility-inhibiting Effect of Crowded Apartment Living in a Tight Housing Market.' American Journal of Sociology 80 (6): 1410-1427.

Fialová, L., D. Hamplová, M. Kučera and S. Vymětalová. 2000. Představy mladých lidí o manželstuí a rodičovství. (Young People's Notions of Marriage and Parenthood) Prague: Sociologické nakladatelství.

Frejka, T. 1980. 'Fertility Trends and Policies: Czechoslovakia in the 1970s.' Population and Development Review 6 (1): 65-93.

Frejka, T. 2008. 'Overview Chapter 5: Determinants of Family Formation and Childbearing during the Societal Transition in Central and Eastern Europe.' Demographic Research 19 (7): 139-170. Retrieved 12 November 2008 (http://www.demographic-research.org/).

Garnett, D. 2000. Housing Finance (Housing Policy E Practice). Coventry: Chartered Institute of Housing.

Garratt, D. 2001. 'Affordability.' Housing Finance 51 (1): 13-20.

Goodman, A. C. 1990. 'Demographics of Individual Housing Demand.' Regional Science and Urban Economics 20 (1): 83-102.

Goodsel, W. 1937. 'Housing and Birth Rate in Sweden.' American Sociological Review 2 (6): 850-859.

Hamplová, D. (ed.) 2007. Děti na psí knížku? Mimomanželská plodnost v České republice. (Children out of Wedlock? Extramarital Fertility in the Czech Republic) Prague: Institute of Sociology, Academy of Sciences of the Czech Republic.

Hamplová, D., S. Pikálková and J. Rychtaříková. 2003. České ženy: vzdělání, partnerství, reprodukce a rodina. (Czech Women: Education, Partnership and Family) Prague: Institute of Sociology, Academy of Sciences of the Czech Republic. 
Hašková, H. 2005. 'Pracující matky a genderové role ve výsledcích mezinárodního longitudinálního průzkumu.' (Working Mothers and Gender Roles in the Results of an International Longitudinal Study) Gender, rovné př́ležitosti, výzkum 6 (1): 22-27.

Klasen, S. and A. Launov. 2006. 'Analysis of the Determinants of Fertility Decline in the Czech Republic.' Journal of Population Economics 19 (1): 25-54.

Kostelecký, T. 2005. 'Postoje obyvatel k situaci na trhu s bydlením a bytové politice: existují v České republice "housing classes"?' (The Czech Population's Opinions on the Housing Situation and Housing Policy: Does the Czech Republic Have 'Housing Classes'?) Sociologický časopis/Czech Sociological Review 41 (2): 253-270.

Kostelecký, T. and D. Čermák. 2004. 'Vliv teritoriálně specifických faktorů na formování politických orientací voličù.' (The Influence of Territorially Specific Factors on the Formation of the Political Attitudes of Voters) Sociologický časopis/Czech Sociological Review 40 (4): 469-488.

Kulhavý, V. and H. Bartáková. 2007. Rodina a zaměstnání II. Mladé rodiny. (Family and Employment II: Young Families) Prague: The Research Institute of Labour and Social Affairs.

Kulu, H. and A. Vikat. 2007. 'Fertility Differences by Housing Type: the Effect of Housing Conditions or of Selective Moves?' Demographic Research 17 (26): 775-802.

Lux, M. 2004. 'Housing the Poor in the Czech Republic: Prague, Brno and Ostrava.' Pp. 23-66 in Too Poor to Move, Too Poor to Stay, edited by J. Fearn. Budapest: Open Society Institute (LGI).

Lux. M. 2007. 'The Quasi-normative Approach to Housing Affordability: The Case of the Czech Republic.' Urban Studies 44 (5-6): 1109-1124.

Lux, M. and F. Kuda (eds.). 2008. Regionální rozdíly v dostupnosti bydlení v České republice. (Regional Differences in Housing Affordability in the Czech Republic) Prague: Institute of Sociology, Academy of Sciences of the Czech Republic.

Lux, M. and P. Sunega. 2006. 'Vývoj finanční dostupnosti nájemního a vlastnického bydlení v průběhu hospodářské transformace v České republice (1991-2003).' (Housing Affordability of Rental and Owner-Occupied Housing over the Course of the Economic Transformation in the Czech Republic) Sociologicky časopis/Czech Sociological Review 42 (5): 851-881.

Lux, M., P. Sunega, T. Kostelecký and D. Čermák. 2003. Standardy bydlení 2002/2003: Finanční dostupnost a postoje občanů. (Housing Standards 2002/2003: Affordability and Citizens' Views) Prague: Institute of Sociology, Academy of Sciences of the Czech Republic.

Mulder, C. H. 2006. 'Population and Housing: a Two Sided Relationship.' Demographic Research 15 (13): 401-412.

Mulder, C. H. and F. C. Billari. 2006. 'Home-Ownership Regimes and Lowest-low Fertility.' Paper presented at the workshop 'Home Ownership in Europe: Policy and Research Issues.' Delft, 23-24 November 2006.

Murphy, M. J. and O. Sullivan. 1985. 'Housing Tenure and Family Formation in Contemporary Britain.' European Sociological Review 1 (3): 230-243.

Musil, J. 1995. 'Czech Housing System in the Middle of Transition.' Urban Studies 32 (10): $1679-1684$.

Národní koncepce rodinné politiky. (National Family Policy) 2005. Prague: Ministry of Labour and Social Affairs.

Paydarfar, A. A. 1995. 'Effects of Multi-Family Housing on Marital Fertility in Iran: Population Policy Implications.' Social Biology 42 (3-4): 214-225.

Peled, T. 1969. 'Problems and Attitudes in Family Planning: Summary of Main Findings.' Unpublished paper, Israeli Institute for Applied Social Research, Jerusalem. 
Plodnost a š̌atečnost žen (Fertility and Nuptiality). 2003. On-line publication of the analysis of 2001 Census data by the Czech Statistical Office. Retrieved 14 December 2009 (http://www.czso.cz/csu/2003edicniplan.nsf/publ/4118-03-\#archiv).

Robinson, W. S. 1950. 'Ecological Correlations and the Behavior of Individuals.' American Sociological Review 15 (3): 351-357.

Robinson, M., G. M. Scobie and B. Hallinan. 2006. 'Affordability of Housing: Concepts, Measurement and Evidence.' New Zealand Treasury Working Paper 06/03. Wellington: New Zealand Treasury.

Rooij, J. M. P. 2003. Monetary Policy and Boom-Busts in Residential Property Markets. Tilburg: Tilburg University.

Rychtaříková, J. 1996. 'Současné změny charakteru reprodukce v České republice a mezinárodní situace.' (Current Changes to the Character of Reproduction in the Czech Republic and the International Situation') Demografie 2: 77-89

Rychtař́ková, J. 2000a. 'Is Eastern Europe Experiencing a Second Demographic Transition?' Acta Universitatis Carolinae Geographica 34 (1): 19-44.

Rychtař́ḱková, J. 2000b. 'Demographic Transition or Demographic Shock in Recent Population Development in the Czech Republic?' Acta Universitatis Carolinae Geographica 35 (1): 89-102.

Rychtaříková, J. 2004. 'Změny generační plodnosti v České republice se zaměřením na vzdělání žen.' (Changes in Generational Fertility in the Czech Republic with a Focus on the Education of Women) Demografie 46 (2): 77-87.

Rychtaříková, J. 2007. 'Porodnost v České republice: současný stav a nedávné trendy.' (Fertility in the Czech Republic: Current Situation and Recent Trends) Pp. 79-94 in Populační vývoj České republiky 2001-2006. Prague: Department of Demography and Geodemography, Faculty of Science of the Charles University.

Šalamounová, P. 2003. Představy o ideálním věku pro zakládání rodiny a reálná data. (Notions of the Ideal Age to Start a Family and Real Data) Prague: Institute for Public Opinion Research of the Institute of Sociology of the Academy of Science of the Czech Republic.

Sobotka, T. 2002. ‘Ten Years of Rapid Fertility Changes in European Post-communist Countries: Evidence and Interpretation.' Working Paper Series 02-1. Groningen: Population Research Centre, University of Groningen.

Sobotka, T. 2003. 'Re-emerging Diversity: Rapid Fertility Changes in Central and Eastern Europe after the Collapse of the Communist Regimes.' Population-E 58 (4-5): 451-486.

Sobotka, T. and W. Lutz. 2009. Misleading Policy Messages from the Period TFR: Should We Stop Using It? European Demographic Research Papers 4. Vienna: Vienna Institute of Demography of the Austrian Academy of Sciences.

Sobotka, T., A. Stáastná, K. Zeman, D. Hamplová and V. Kantorová. 2008. ‘Czech Republic: A Rapid Transformation of Fertility and Family Behaviour after the Collapse of State Socialism.' Demographic Research 19 (Special Collection): 403-454.

Sobotka, T., K. Zeman and V. Kantorová. 2003. 'Demographic Shifts in the Czech Republic after 1989: A Second Demographic Transition View.' European Journal of Population 19 (3): 249-277.

Štastná, A. 2007. ‘Druhé dítě v rodině - preference a hodnotové orientace českých žen.' (A Second Child in the Family: The Preferences and Values of Czech Women) Sociologický časopis/Czech Sociological Review 43 (4): 721-745.

Sunega, P. 2003. 'Objektivní a subjektivní hodnocení finanční dostupnosti bydlení v ČR v průběhu 90. let.' (Objective and Subjective Evaluations of Housing Affordability in Prague during the 1990s) Sociologické texty 05/2003. Prague: Institute of Sociology, Academy of Sciences of the Czech Republic. 
Sunega, P. 2005. 'Efektivnost vybraných nástrojů bytové politiky v České republice.' (The Effectiveness of Selected Housing Policy Subsidies in the Czech Republic) Sociologický časopis/Czech Sociological Review 41 (2): 271-300.

Sýkora, L. and D. Posová. 2007. 'Specifika suburbanizace v post-socialistickém kontextu: nová bytová výstavba v metropolitní oblasti Prahy 1997-2005.' (The Specific Features of Suburbanisation in a Post-socialist Context: New Housing Construction in the Metropolitan Area of Prague) Geografie - sborník ČGS 112 (3): 334-356.

Tan, S. B., J. Lee and S. S. Ratnam. 1978. 'Effects of Social Disincentive Policies on Fertility Behavior in Singapore.' American Journal of Public Health 68: 119-124.

Thompson, W. S. 1938. 'The Effect of Housing upon Population Growth.' The Milbank Memorial Fund Quarterly 16 (4): 359-368.

Van de Kaa, D. J. 1987. 'Europe's Second Demographic Transition.' Population Bulletin 42 (1): 1-57.

Vobecká, J. 2009a. Spatial Dynamics of Population and Its Structural Changes in the Czech Republic after 1989. Unpublished dissertation manuscript, Université de Bourgogne, Dijon.

Vobecká, J. 2009b. ‘Dojížd’kový přístup k vymezení městského, příměstského a venkovského obyvatelstva v České republice.' (The Commuting Approach to Delimiting Urban, Suburban, and Rural Populations in the Czech Republic) Demografie 50 (1): 14-22.

World Population Prospects: The 2004 Revision. 2005. New York: Department of Economic and Social Affairs, Population Division, United Nations. 